\title{
Erratum to: Incidental findings of uncertain significance: To know or not to know - that is not the question
}

Bjørn Hofmann ${ }^{1,2}$

\section{Erratum}

Following publication of the original article in BMC Medical Ethics [1], it was brought to my attention that the following sentences are incorrect:

"Moreover, genetics professionals appear to think that to know is better than not to know [25] even when the information is actionable [26]." This sentence should read: Moreover, genetics professionals appear to think that to know is better than not to know [25] even when the information is not actionable [26].

"Let me therefore now turn to arguments for a right to know before summarizing the arguments in Table 1."

This sentence should read: Let me therefore now turn to arguments for a right not to know before summarizing the arguments in Table 1.

I apologise for the inconvenience this may have caused.

\section{Received: 13 May 2016 Accepted: 21 June 2016}

Published online: 23 June 2016

\section{Reference}

1. Hofmann B. Incidental findings of uncertain significance: To know or not to know - that is not the question. BMC Med Ethics. 2016;17:13.

\footnotetext{
Correspondence: b.m.hofmann@medisin.uio.no

${ }^{1}$ Norwegian University of Science and Technology, Gjøvik, Norway

${ }^{2}$ Centre for Medical Ethics, University of Oslo, PO Box 1130 Blindern, N-0318 Oslo, Norway
}

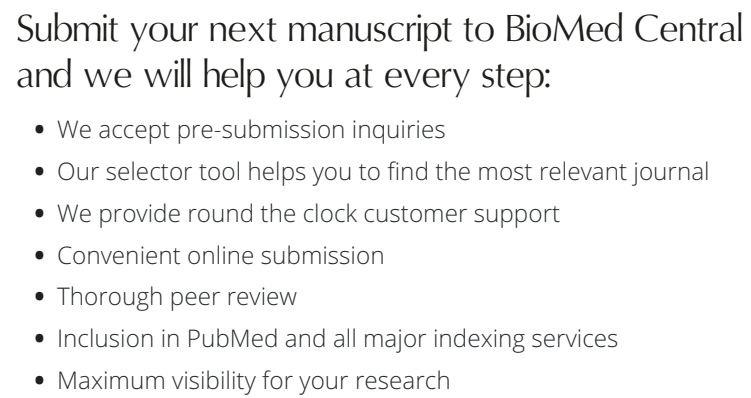

- We accept pre-submission inquiries

- Our selector tool helps you to find the most relevant journal

- We provide round the clock customer support

- Convenient online submission

- Thorough peer review

- Inclusion in PubMed and all major indexing services

- Maximum visibility for your research

Submit your manuscript at www.biomedcentral.com/submit

() BioMed Central 